\title{
The Effectiveness of a Mathematics Learning Program Based on the Mind Habits in Developing Academic Achievement Motivation and Creative Thinking among Prince Sattam Bin Abdulaziz University Students
}

\author{
Sahar Abdo Mohamed Elsayed ${ }^{1} \&$ Heba Mohamed Nasef ${ }^{2}$ \\ ${ }^{1}$ Associate Professor of Curriculum and Mathematics Methodology, Faculty of Education in Dalam, Prince Sattam \\ Bin Abdulaziz University, Al-Kharj, Saudi Arabia \\ 2 Assistant Professor of Educational Psychology, Faculty of Education in Dalam, Prince Sattam Bin Abdulaziz \\ University,Al-Kharj11942, Saudi Arabia, women's College of art, education and science, Ain Shams \\ University,Egypt \\ Correspondence: Sahar Abdo Elsayed, Associate Professor of Curriculum and Mathematics Methodology, Faculty of \\ Education in Dalam, Prince Sattam Bin Abdulaziz University, Al-Kharj11942, Saudi Arabia.
}

Received: August 17, 2020

Accepted: September 22, 2020

Online Published: September 23, 2020

doi:10.5430/ijhe.v10n1p55

URL: https://doi.org/10.5430/ijhe.v10n1p55

\begin{abstract}
The research aimed at identifying the effectiveness of a mathematics learning program based on the Mind habits in developing academic achievement motivation and creative thinking among University students. To collect the data, the researchers used the academic achievement motivation scale (Elsayed, 2012) and the creative thinking in Mathematics test (Prepared by the Researchers). The study methodology based on the semi experimental method and the statistical program SPSS was used to analyze the collected data. The sample was chosen randomly from the mathematics department. The results found that there are statistically significant differences between the scores of the academic achievement motivation and the creative thinking in favor of the post- applications at (0.01) level and this showed that the program has positive effects in developing the academic achievement motivation and the creative thinking in Mathematics among Prince Sattam Bin Abdulaziz University Students.
\end{abstract}

Keywords: Mathematics learning, Mind habits, academic achievement motivation, creative thinking, Higher Education

\section{Introduction}

Recent trends in teaching mathematics have led to developing the levels of creative thinking. So, the objectives of the University's academic programs should be based on developing the creative capabilities, critical thinking skills, the Mind processes, and the mathematical problem-solving. (Ellen, 2001,304)

Since 1950 creative thinking was an important scientific research problem in many countries. Developing humanity depends on creative thinking that enables the person to make more innovations or contributions to be able to face daily problems. (Almchrefi, 2005, 35), and the student who thinks creatively reaches his goals at the least time, effort, and cost. (Aldabagh, 2008, 4).

The study (Anncmie Desoete, 2007) emphasized that the importance of the Mind habits in teaching mathematics that increase the achievement motivation.

\section{Research Problem}

The researchers wanted to answer the following main question: What is the effectiveness of a program based on the Mind habits in developing academic achievement motivation and creative thinking in Mathematics among Prince Sattam Bin Abdulaziz University students?

The sub-questions:

1) What are the components of the proposed mathematics learning program that based on the Mind habits?

2) Does the Mind habits program develop: 
A) The academic achievement motivation among the study sample?

B) The creative thinking in Mathematics among the Sample?

\subsection{The Aim}

The research deals with one of the most important aims in developing humanity which is developing the thinking skills. So the researchers aimed at identifying the effectiveness of the mathematics learning program based on the Mind habits in developing both academic achievement motivation level and creative thinking Skills in Mathematics among the study sample?

\subsection{The added value of the research in Mathematics Learning are}

1) Highlighting the Mind habits that are related to the labor - market especially, academic achievement motivation, and creative thinking in mathematics learning in general.

2) Fulfilling the society's main objective of active learning.

3) Forming an ideal to achieve nationally and internationally, by relating our recent age where we live to the progressive technology.

4) Graduating efficiency students know how to think, plan, and be creative.

\subsection{The Importance}

The research can help the following:

1) Faculty members: Identifying the Mind habits skills, academic achievement motivation dimensions, and creative thinking skills in mathematics.

2) Students: Providing an attractive learning environment that increases their participation in the educational situation by using the Mind habits programs, and developing the academic achievement motivation and creative thinking in Mathematics.

3) Quality and Accreditation: Achieving the Universities' strategic objective which means "continuous improvement of teaching and learning processes", by activating self-learning, as well as building modern strategies for teaching and learning.

4) Researchers: using the results and the recommendations in other new related studies.

\section{Methodology}

\subsection{The Research Methodology}

The semi-experimental method (one-group experimental design), the analytical descriptive method of the references and literary survey, and SPSS were used in analyzing and interpreting data and statistics.

\subsection{The Research Limits}

1) The study sample was selected randomly. It consisted of 22 students from the fifth-level, Education Faculty in Dalam, section 129, in the second semester of the academic year 1439/1440 H, at Prince Sattam bin Abdulaziz University, Al-Kharj, Riyadh, which was taught by using the study program.

2) The thinking methods unit of the methodology curriculum (1); for its relation to the Mind habits in a mathematics learning program, academic achievement motivation, and creative thinking skills.

\subsection{Research Tools}

1) The academic achievement motivation scale in mathematics (Elsayed, 2012).

2) The creative thinking in Mathematics test (prepared by the researchers).

3) The experimental tool: A program based on the Mind habits (prepared by the researchers).

\section{Definitions}

\section{Mind Habits:}

Mind habits definition is considered as an important educational definition that emerged at the beginning of the 20th century and these habits are one of the Marzano Learning Model dimensions. The Mind habits aim to employ cognitive and emotional processes (self-regulation, creative thinking, and critical thinking) during educational situations. Marzano defines them as "a relationship between the student's thinking style during problem solving and his will to think" (Marzano et al., 1993). 
Alqady defines them: "cognitive habits that guide students' behavior and motivate them to learn; to achieve a particular goal and help them focus on the most important priorities"(Alqady et al., 2016, 44).

The Mind habits in the current research are defined as "a set of creative behaviors used in organizing educational experiences in the research program". These Mind habits are sixteen as (Costa, Kallick, 2000):

1) The perseverance in the learning process.

2) Controlling within the rush degree.

3) Listening to students with understanding and empathy.

4) Thinking flexibly.

5) Building meta-cognition processes.

6) Questioning and asking problems.

7) Applying previous experience in new situations.

8) Working hard for scientific accuracy.

9) Thinking and communicating accurately and clearly.

10) Using senses in data collection.

11) Creativity, Imagination, and Innovation.

12) Responding with surprise and desire.

13) Taking the calculated risk.

14) Searching for thinking cheerfully.

15) Reciprocal thinking.

16) Desiring and attitude to learning.

\section{Academic Achievement Motivation:}

It is the motivation that seeks success or achieves the desired end, or the drive to overcome obstacles, or to complete the performance of difficult tasks quickly (Alhefnee, 1994, 12). It is also a state of change resulting from the activity of an organism that is characterized by stimulus and directed behavior to achieve an aim. (AlKhuly, 2002, 46).

The academic achievement motivation was defined as the students' curiosity and their perseverance in carrying out the mathematical tasks and avoiding the failures.

\section{Creative thinking:}

Creative thinking was identified by Torrance (1967) as the process in which the individual became sensitive to problems. Or " The individual ability to produce a fluency, spontaneous flexibility, originality and distant correlations production in response to a problem or a stimulating situation" (Khayrallah, 1975, 5), and it was defined as "A Mind process in which the individual produces something new and innovative, characterized by originality and diversity of ideas or objects and the linking of elements with relationships to solve problems by a new component including the fluency, the flexibility, originality, and relationships" (Aldapagh, 2008, 13).

The procedural definition can be expressed by a measured score on the creative thinking in Mathematics test.

\section{The Theoretical Framework}

\section{The Mind habits:}

The Mind habits according to Marzano et al. (1993) include positive attitudes and the learning process perceptions. But Arthur Costa and Bina Kallick designed a thinking habits hierarchy that known as the Mind habits, the model includes the separating thinking skills such as comparing, classifying, formulating the hypothesis, thinking strategies as problem - solving, and making - decision, creative thinking, designing unique models; cognitive abilities such as active open thinking, and finding alternatives. Costa and Kalik subsequently proposed an integrated model that includes 16 Mind habits (Costa, Kallick, 2000).

Qatami added that the Mind habits are defined as the knowledge representation to achieve the aim, and use experiences in different situations to reach a state of rest and pleasure. He also referred to it as structured, organized thinking, which includes mechanisms and strategies related to the aim and then planning to achieve it consciously. So those who possess Mind habits have the ability and the will (Qatami, 2007, 14). 


\section{The Mind habits classification:}

The Science, Mathematics, and Technology Project (2001) proposed some Mind habits that may play a prominent role in developing the individual: integration, diligence, justice, curiosity, openness to new ideas, knowledge-based skepticism, imagination, numerical skill, guessing, observation, Communication, and critical response skill. (AlHarthy,2007, 39-40)

Stephen Covey (2000) identified seven Mind habits:

1) Initiative.

2) Plain goal.

3) Prioritizing (begin with the most important).

4) Thinking about mutual gain (seeking others pleasure).

5) Understanding first then try to understand others.

6) Cooperation.

7) Reviewing, evaluating the self, and developing the weaknesses.

Manal Souttohy classified the Mind habits into: observation, details and Mind perception, questions and hypotheses, Mind planning formulation, determination, and attempt (Soutohy, 2011, 42).

While Marzano defined the Mind habits in three broad categories (Marzano et al., 1993, 240-244):

1) Self-regulation thinking:

Mind habits involve self-regulation so the learner is aware of his thinking, capable of systematic planning, able to use the learning resources to reach the solution, able to assess the effectiveness of his various actions to find a solution for the facing problem.

2) Critical Thinking:

The critical thinking learner is characterized by Seeking precision in his work, and he is open-minded. The learners can obtain this thinking by controlling discussions about different ideas, playing roles in historic events, holding seminars and debates, watching television programs that express different viewpoints, and analyzing different articles and topics.

3) Creative thinking:

It is characterized by that:

A) It is a complex, objective, comprehensive, and productive Mind activity.

B) It is oriented towards finding a problem solution or reaching original results.

C) It is complex thinking because it contains interrelated cognitive, emotional, and ethical elements that ultimately form a unique state of Mind. (Alaza, 2002 , 265).

Meader (1998) believes that creative thinking consists of two elements: Convergent, which includes the correctness, and agreed with information, and Divergent thinking that is used to generate and derive various ideas (Sawyer et al., 1990). It is a process of interpersonal and intrapersonal by which the original and important outcomes can be developed (Al-Atoom, 2009, 139-140). The Arab Council of Gifted and Talented (2002) clarifies that creative thinking is based on the creation and depends on the appropriate environment, the individual's goals, Mind processes, experiences, and personal characteristics. (Manssi, 1991, 241).

Torrance tests referred to Fluency as the most important creative thinking ability. It means the ability to generate a large number of alternatives, synonyms, ideas, problems or uses when responding to a particular stimulus which in essence is a process of recall of information, or experiences, or concepts previously learned (Garwan, 1999, 82).

1) The fluency according to (Al-Atoom, 2009, 141), (Almeshrefi, 2005, 49) includes:

A) The Ideational Fluency: refers to "the ability to produce the largest number of expressions that belong to a particular type of ideas at a specific time, and it is revealed by using tests that require subjects to undertake certain activities ".

B) The verbal fluency: it is the ability to produce as many words as possible where available certain conditions "appear in the form of the ability to produce a greater number of words that contain certain letters. This ability is especially noticeable among creators in the humanities and the arts fields. 
C) the associational fluency: "The ability to produce as many primary units as possible with certain characteristics such as a relationship of similarity, and the production of new ideas in a position that requires less control, the importance of the type of response, and the importance of the number of responses which is issued by the researcher at a specific time ".

D) The expressional fluency: means "the ability to express ideas fluently or to formulate useful phrases", Guilford described it as "rapid thinking inappropriate related words".

2) Flexibility can be expressed in two forms (Khairallah, 1981, 363), (Moawad, 2000, 174):

A) Spontaneous flexibility: the ability to change the thinking of freedom without directing towards a particular solution and the possibility of changing the person for his thinking in new directions to produce as many as possible of different ideas in ease and ease.

B) Adaptive flexibility: refers to the ability to rapidly change thinking and Mindset to cope with new situations and changing problems. The person enjoys this ability through tests that give the subject a problem, and then asks him to find a variety of solutions, although there are some traditional solutions known to the problem, they are rejected because what is required in such a situation is diversity.

3) Originality: "the ability to produce as quickly as possible the indirect and uncommon responses and ideas which are at the same time acceptable and appropriate to the goal and originality means novelty and wit" (Moawad, 2000, 174).

4) Accuracy of details: It is the skill to explore alternatives to deepen the idea. Torrance defined it as "the ability to give details of a particular idea or to give further additions to the ideas" (Moawad, 2000, 174).

\section{The educational importance of the Mind habits:}

The mathematics programs have great importance in teaching and learning in the twenty-first century, especially the mathematics programs that are based on the Mind habits.

Because of the importance of mathematics in all areas of daily life, it is clear that the importance of developing students' skills to achieve maximum effectiveness in teaching and learning to meet the needs of society (Elsayed, 2019).

It can be summarized as follows (Said, 2006, 431), (Abdel Wahab, 2009, 2), and (Costa \& Kallic, 2000):

1) Directing and organizing the learning process, assuming responsibility, and using the thinking skills to guide and improve thinking.

2) Mixing critical and creative thinking as well as self-organizing abilities to reach the best performance.

3) Finishing any task in a short time.

4) Focusing on independence and taking responsibility when achieving any task.

5) Choosing the educational situation procedures that the student is going through.

6) Proficiency in dealing with information from various sources to achieve awareness, understanding, excellence, and the use of the information.

7) Understanding positive attitudes and perceptions about learning and social and collaborative skills use.

8) Developing the achievement, and dealing with daily life situations effectively.

9) Paying attention to details, flexibility and awareness to make results and communicate well.

\section{The proposed Mind habits mathematics learning program:}

The program was based on Costa and Kallic model that contains of 16 Mind habits (2000), according to the problem-solving strategies by George Pulia in mathematics (Ghandourah, 1997) (Aqeelan, 2000), (Al-Sawai, 2004), (Saleh, 2006), and (Badawi, 2008), and the scientific chains of mathematics (McGraw-Hill) (Elsayed, 2019), which is compatible with the constructive theory in learning mathematics that encourages innovation, organizing and presenting educational experiences; that is relevant to the academic achievement motivation and the creative thinking skills in Mathematics, which the model aimed to develop. As it contributes to problem - solving in a systematic and organized way that achieves effective communication through encouraging writing, dialogue, and discussion, and teamwork among students, and projects. So their academic motivation increases, on one hand, and their athletic sense develops, on the other hand (Chulvi, et., al, 2012), (Varol, Farran, 2007). As it is shown in the following table: 
Table 1. The Mind habits program

\begin{tabular}{|c|c|c|}
\hline No. & The Mind habits & The program basis \\
\hline 1 & $\begin{array}{l}\text { Perseverance of the } \\
\text { student in the learning } \\
\text { process }\end{array}$ & $\begin{array}{l}\text { Support the student continuity in the learning activities within the educational situation and } \\
\text { outside, and motivates them to benefit from successful educational experiences with the attempt } \\
\text { and experimentation individually and collectively. }\end{array}$ \\
\hline 2 & Controlling within rush & $\begin{array}{l}\text { Take the calculated risk to design educational situations and problems that challenge their } \\
\text { abilities according to the information available. }\end{array}$ \\
\hline 3 & $\begin{array}{l}\text { Listening } \\
\text { understanding } \\
\text { empathy }\end{array}$ & $\begin{array}{l}\text { Students achieve specific tasks through the skill of development and follow-up through } \\
\text { collaborative learning activities designed to support: group discussions, listening to others, } \\
\text { questioning for accurate understanding, time estimation, enhancing others, and appreciating } \\
\text { their ideas while working and speaking. }\end{array}$ \\
\hline 4 & Thinking flexibly & $\begin{array}{l}\text { Support students to discuss and evaluate their ideas and solutions in the light of others' ideas } \\
\text { and solutions through activities related to thinking on multiple paths. }\end{array}$ \\
\hline 5 & $\begin{array}{l}\text { Building metacognitive } \\
\text { Processes }\end{array}$ & $\begin{array}{l}\text { Directly related to the post- practice, by including activities that support students in reading, } \\
\text { organizing, evaluating, and modifying their thinking. }\end{array}$ \\
\hline 6 & $\begin{array}{l}\text { Asking and providing } \\
\text { problems }\end{array}$ & $\begin{array}{l}\text { ng and experimenting through educational activities designed to } \\
\text { ing skills. }\end{array}$ \\
\hline 7 & 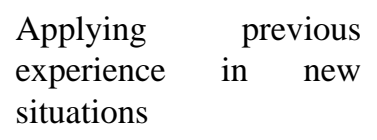 & $\begin{array}{l}\text { d develop the abilities and experiences of the student previously learned, through } \\
\text { signed to do so. }\end{array}$ \\
\hline 8 & $\begin{array}{l}\text { Doing an effort for } \\
\text { scientific accuracy }\end{array}$ & $\begin{array}{l}\text { arch skills, experimentation, and accuracy of scientific results, through the } \\
\text { entation, surveying, and problem- solving. }\end{array}$ \\
\hline 9 & $\begin{array}{l}\text { Thinking and } \\
\text { communicating accurately and clearly }\end{array}$ & $\begin{array}{l}\text { his habit is related to thinking, and the need for activities that require communication between } \\
\text { udents to justify their results and choices and clarify their thinking paths. }\end{array}$ \\
\hline 10 & $\begin{array}{l}\text { Using senses to collect } \\
\text { data }\end{array}$ & $\begin{array}{l}\text { Design activities to test students' abilities to use the five senses to gather data about a problem } \\
\text { or phenomenon. }\end{array}$ \\
\hline 11 & $\begin{array}{l}\text { Creation, imagination, } \\
\text { and innovation }\end{array}$ & $\begin{array}{l}\text { Produce new ideas of fluency, flexibility, and originality through the development of thinking } \\
\text { activities. }\end{array}$ \\
\hline 12 & $\begin{array}{l}\text { Responding with } \\
\text { surprise and desire }\end{array}$ & $\begin{array}{l}\text { It is related to building the students' abilities to be sensitive to problems, to be able to identify } \\
\text { them, and take initiative in dealing with them. }\end{array}$ \\
\hline 13 & Taking risk management & $\begin{array}{l}\text { Related to students' research on intellectual adventure, and experimentation to test the } \\
\text { hypotheses and balance between the adventure spirit and its unaccounted consequences. }\end{array}$ \\
\hline 14 & $\begin{array}{l}\text { Researching in thinking } \\
\text { with fun }\end{array}$ & Organize learning environments based on collaboration and enjoyment of educational work. \\
\hline 15 & Mutual Thinking & $\begin{array}{l}\text { Associated with the ninth practice and developing it, as group thinking is aimed at developing } \\
\text { the cognitive structure of the individual constantly. }\end{array}$ \\
\hline 16 & $\begin{array}{l}\text { Desiring and attitude to } \\
\text { learn }\end{array}$ & $\begin{array}{l}\text { This is the result, noting the building of positive attitudes among students, with increased } \\
\text { motivation and innovation. }\end{array}$ \\
\hline
\end{tabular}

Table (1) illustrates the program main principles that enrich and evaluate individually or collectively using the communication means, digital databases, and open discussions through the Blackboard.

Thus, the proposed program based on Mind habits helped in answering the first question of the research.

\section{Academic achievement motivation:}

The achievement motivation is one of the important humanitarian motivation system aspects because it is important to understand many educational problems and it was given greater attention than other social motives (Al Ghamdi, 2000, 76). 


\section{The academic achievement motivation scale dimensions:}

The researchers used five dimensions to develop achievement motivation(Note 1): curiosity, perseverance, enjoyment, ambition, failure - avoidance, which agrees with most of the following educational studies and researches (Moussa, 1991, 5-15), (Elsayed, Ahmed, 2005, 22-23), (Al-Safy, 2001, 61-90), (Lutfallah, 2005, 34-35), (Abdelmalik, 2007, 65), as follows:

1) Curiosity: The desire to discover the facts of the ambiguous things in the situations comes out of the student's sensations.

2) Perseverance: It means that the student is determined to achieve his aim despite the difficulties that prevent him from achieving the ability to keep his activity to the maximum extent possible.

3) Enjoyment: A student's sense of happiness and he seeks to achieve the aims to reduce boredom or faced difficulties.

4) Ambitious: The student's desire to increase his knowledge and skills, and to achieve a prestigious position, and the student's desire to look forward to the future.

5) Avoid failure: The student's search for actions that prevent his failure, and the desire to overcome his failures quickly; to achieve further progress of the aims.

Rana Abu-Zaarour (2004) conducted a study that aimed at finding out the effect of computer-aided Mind habits. She used "Visual Basic" on mathematics achievement and deferred achievement motivation for seventh - grade pupils in the governmental city of the Education Directorate in Nablus Governorate. There was a statistically significant difference at (0.01) level for the experimental group (Abu Zaarour, 2004).

Khalid Al Rabghi (2005) found that there is a relationship between motivation and the Mind habits where differences in achievement motivation are due to the Mind habits prevalence (Al Rabghi, 2005).

The Giyal study (2006) suggested that Mind motivation involves dimensions such as creative problem solving, cognitive integration, Mind focus, and learning orientation. These dimensions are characteristics of individuals who use Mind habits effectively. (Giyal, 2006).

Chan Min and Charles study (2011) designed Mind habits program on the Internet for therapeutic mathematics to study its effect on achievement motivation. The results showed that the experimental group fulfilled higher levels of achievement motivation and discussed the implications of interventions and systems to raise students' achievement motivation (Chan Min Kim, Charles B, 2011).

\section{Summary of the previous studies:}

1) The current study agreed with the previous studies aim in developing academic achievement motivation.

2) The direct method used in mathematics education and learning programs based on the Mind habits.

3) A program based on the Mind habits is used as an independent variable.

4) The academic achievement motivation scale in mathematics is used by the researchers among the Sample.

\section{Creative thinking:}

Creative thinking in Mathematics test was prepared by the researchers (Note 2). It aimed at identifying creative thinking skills in mathematics among the sample. The test consisted of 12 questions and each question has many different correct solutions.

Al-Ja'afra study (2001) aimed at comparing creative thinking and achievement motivation among the most academically outstanding and talented students in Jordan. The sample was students (boys and girls) in the tenth grade were divided into three programs. The study found that there is a relation between developing creative thinking and achievement motivation, and there aren't significant differences between girls and boys (Al-Ja'afra, 2001).

Abu Hilal and Al-Tahan study (2002) found that there is a relationship between creative thinking and academic achievement in a sample of talented students. The study was conducted in the United Arab Emirates (406 $6^{\text {th }}$ primary pupils) between intelligence, innovation, and achievement (Abu Hilal, Al-Tahan, 2002).

Nasef (2010) found that there is a relation between creative thinking skills and critical thinking skills and academic achievement motivation. The study developed thinking skills through enrichment programs that lead to the development of academic achievement motivation (Nasef, 2010). 


\section{Summary of the studies' results:}

1) The current study agreed on developing the creative thinking skills in Mathematics.

2) The relation between developing creative thinking skills and the achievement motivation in Mathematics.

3) A program based on the Mind habits is used as an independent variable.

4) The program was applied to university students.

The research based on the Mind habits (independent variable), and few of these studies were conducted at the university level, which increased the two researchers motivation to conduct this research, as well as there were no study deal with the Mind habits program effective in developing academic achievement motivation and creative thinking in Mathematics among University students.

\section{Research hypotheses:}

According to the previous studies, the hypotheses are:

1) There is a statistically significant difference between the average scores of the pre-and the post-application of the academic achievement motivation scale in favor of the post-application.

2) There is a statistically significant difference between the average scores of the pre-and the post-application of the creative thinking in Mathematics test in favor of the post-application.

3) The program based on the Mind habits is effective in developing academic achievement motivation and creative thinking in Mathematics.

\section{The Results Interpretation}

The researchers used the T-Test to test the hypotheses validity and used the practical significance (effect size) to confirm the first and second hypotheses validity. The results were:

\subsection{The First Hypothesis Result}

"There is a statistically significant difference between the average scores of the pre-and the post-application of the academic achievement motivation scale in favor of the post-application", the research results:

Table 2. The achievement motivation Scale statistical Indicators

\begin{tabular}{lllllllll}
\hline item & Maximum & Minimum & \multicolumn{2}{l}{ Post- application } & \multicolumn{3}{l}{ Pre- application } \\
\cline { 5 - 8 } & limit & limit & Maximum & Minimum & total & Maximum & Minimum & total \\
Curiosity & 15 & 5 & 15 & 12 & 270 & 8 & 5 & $\mathbf{1 2 5}$ \\
Perseverance & 15 & 5 & 15 & 11 & 267 & 9 & 5 & $\mathbf{1 2 6}$ \\
Enjoyment & 15 & 5 & 15 & 12 & 270 & 10 & 5 & $\mathbf{1 2 9}$ \\
Ambitious & 15 & 5 & 15 & 10 & 262 & 8 & 5 & $\mathbf{1 2 4}$ \\
Avoid failure & 15 & 5 & 15 & 12 & 269 & 9 & 5 & $\mathbf{1 2 5}$ \\
Whole scale & 75 & 25 & 75 & 57 & 1338 & 44 & 25 & $\mathbf{6 2 9}$ \\
\hline
\end{tabular}

Table (2) showed the academic achievement motivation scale statistical indicators, the maximum score for the students was (75) and the minimum score was (25). The maximum score obtained by the students in the postapplication was (75) and the minimum was (57). The total score was (1338), while the maximum score obtained by the students in the pre- application (44) and the minimum was (25), and the total score was (629).

The following table showed the achievement motivation scale "T" value: 
Table 3. The achievement motivation scale "T" value

\begin{tabular}{|c|c|c|c|c|c|c|}
\hline item & Post- app & lication & Pre- appli & $\mathrm{N} 2=22$ & $T$ value & Significance \\
\hline & Average & standard deviation & Average & standard deviation & & \\
\hline Curiosity & 14.86 & 1.92 & 8.61 & 2.24 & 2.97 & \\
\hline Perseverance & 14.72 & 1.98 & 8.75 & 1.97 & 2.89 & Significant \\
\hline Enjoyment & 14.73 & 2.12 & 8.41 & 1.82 & 2.89 & \\
\hline Ambitious & 14.46 & 2.48 & 6.99 & 1.24 & 2.95 & \\
\hline Avoid failure & 15.20 & 2.48 & 7.74 & 1.62 & 3.27 & \\
\hline Whole scale & 74.14 & 7.54 & 40.53 & 10.72 & 3.76 & \\
\hline
\end{tabular}

Table (3) showed that the group average scores in the academic achievement motivation scale post- application were (74.14) and the standard deviation (7.54), while the results indicated that the group average score in the pre-implementation of the academic achievement motivation scale was (40.53) and the standard deviation (10.72), and there were statistically significant differences, where the calculated $\mathrm{T}$ value was (3.76), which was greater than the $\mathrm{T}$ value (0.01) in favor of the academic achievement motivation scale post -application.

These showed the first hypothesis validity and answered the research first question.

\subsection{The Second Hypotheses Results}

"There is a statistically significant difference between the average scores of the pre-and the post-application of the creative thinking in Mathematics test in favor of the post-application ", the results:

Table 4. The creative thinking in Mathematics Test Statistical indicators

\begin{tabular}{lllllllll}
\hline items & $\begin{array}{l}\text { Minimum } \\
\text { limit }\end{array}$ & $\begin{array}{l}\text { Maximum } \\
\text { limit }\end{array}$ & \multicolumn{2}{l}{ Pre- application } & N2=22 & \multicolumn{2}{l}{ Post- application } & N1=22 \\
\cline { 4 - 8 } Fluency & 30 & 1 & Minimum & Maximum & Total & Minimum & Maximum & Total \\
Flexibility & 15 & 1 & 30 & 21 & 459 & 18 & 8 & 280 \\
Originality & 35 & 1 & 15 & 8 & 220 & 8 & 4 & 114 \\
$\begin{array}{l}\text { Details } \\
\begin{array}{l}\text { Whole creative } \\
\text { thinking }\end{array}\end{array}$ & 110 & 1 & 35 & 19 & 479 & 12 & 6 & 178 \\
\hline
\end{tabular}

Table (4) showed that the creative thinking in the Mathematics test statistical indicator, the maximum limit that the female students got (110) and the minimum score was (4). The maximum score obtained by the students in the post application was (110) and the minimum was (68). The total was (1612), while the maximum obtained by the students in the pre- application was (56) and the minimum was (25), and the total was (484).

The following Table showed the creative thinking in Mathematics test " $\mathrm{T}$ " value:

Table 5. The creative thinking skills in Mathematics test "T" value

\begin{tabular}{|c|c|c|c|c|c|c|c|}
\hline \multirow[t]{2}{*}{ item } & & \multirow{2}{*}{$\begin{array}{l}\begin{array}{l}\text { Post- } \\
\text { N1=22 }\end{array} \\
\text { Average }\end{array}$} & \multirow{2}{*}{$\begin{array}{r}\text { application } \\
\text { standard deviation }\end{array}$} & \multicolumn{2}{|c|}{ Pre- application } & \multirow[t]{2}{*}{ T value } & \multirow[t]{2}{*}{ Significance } \\
\hline & & & & Average & $\begin{array}{l}\text { standard } \\
\text { deviation }\end{array}$ & & \\
\hline Fluency & & 26.38 & 3.032 & 16.61 & 2.56 & 3.15 & \\
\hline Flexibility & & 12.11 & 1.875 & 6.15 & 1.57 & 3.01 & Significant \\
\hline Originality & & 25 & 4.28 & 10.36 & 1.72 & 3.35 & \\
\hline Details & & 24.11 & 3.46 & 14 & 2.14 & 3.13 & \\
\hline $\begin{array}{l}\text { Whole } \\
\text { thinking }\end{array}$ & creative & 89 & 7.56 & 46.76 & 14.49 & 3.67 & \\
\hline
\end{tabular}


Table (5) indicated that the group average scores in the creative thinking skills in Mathematics test post-application were (89) and the standard deviation (7. 56), while the results indicated that the group average scores in the creative thinking skills in Mathematics test pre-implementation was (46.76) and the standard deviation (14.49), and there were statistically significant differences, where the calculated $\mathrm{T}$ value was (3.67), which is greater than the value of the table $\mathrm{T}(0.01)$ in favor of the creative thinking skills in Mathematics test post-application.

These results showed the second hypothesis validity and answered the second question.

\section{The third hypothesis results:}

"The program based on the Mind habits is effective in developing academic achievement motivation and creative thinking in Mathematics ", the research results:

The program practical significance impact is:

The Effect Size ( $\eta 2)$ (Rosnow \& Rosenthal, 1996): $\quad \eta 2=\frac{\mathrm{T} 2}{\mathrm{~T} 2+\mathrm{df}} \quad \mathrm{T}^{2}=\mathrm{T}$ Value Square $\mathrm{df}=21$

By calculating the practical significance of the differences between the pre and the post application of the academic achievement motivation scale:

Table 6. Calculate the practical significance of the differences between the pre and the post application of the academic achievement motivation scale

\begin{tabular}{llllc}
\hline Level & T value & degrees of freedom & n2 & practical significance type \\
\hline Curiosity & 2.97 & 21 & 0.30 & \\
Perseverance & 2.89 & 21 & 0.29 & Strong \\
Enjoyment & 2.89 & 21 & 0.29 & \\
Ambitious & 2.95 & 21 & 0.30 & \\
Avoid failure & 3.27 & 21 & 0.34 & \\
Whole scale & 3.76 & 21 & 0.40 & \\
\hline
\end{tabular}

From Table (6) The (n) 2 value was greater than 0.14 indicating that the practical significance was strong, as well as the program impact in developing the academic achievement motivation, which indicated the first hypothesis validity.

Also there were statistically significant differences in the Mind habits program at the $(0.01)$ level between the research group average scores of the pre- and post- applications in favor of the post-application. This program included non-traditional teaching methods such as learning through discovering, collaborative learning, and the use of reinforcement various types. And the students' satisfaction raised the achievement motivation level through the mathematics tasks that put students in situations that challenge their thinking and inspire curiosity and perseverance, and this confirmed the program based on the Mind habits effectiveness in developing the research group academic achievement motivation in the post - application, which also demonstrated the first hypothesis validity.

By calculating the practical significance of the differences between the pre and the post- application of creative skills in the Mathematics test:

Table 7. Calculate the practical significance of the differences between the pre- and the post- application of creative skills in the Mathematics test

\begin{tabular}{lllll}
\hline Level & T value & degrees of freedom & $\mathbf{n 2}$ & practical significance type \\
\hline Fluency & 3.15 & 21 & 0.32 & \\
Flexibility & 3.01 & 21 & 0.30 & Strong \\
Originality & 3.35 & 21 & 0.35 & \\
Details & 3.13 & 21 & 0.32 & \\
Whole creative thinking & 3.67 & 21 & 0.39 &
\end{tabular}

From Table (7) The (n)2 value was greater than 0.14 indicating that the practical significance is strong, as well as the program impact in developing creative thinking skills in Mathematics, which indicated the second hypothesis validity. 
Also there were statistically significant differences in the Mind habits program at the $(0.01)$ level between the research group average scores in the pre- and post- applications in favor of the post-application. This program included non-traditional teaching methods confirmed the effectiveness in developing creative thinking in the post application, which also demonstrated the second hypothesis validity.

These showed the third hypothesis validity.

\section{General Conclusion}

By interpreting the research results, it was found that they agree with previous studies, as (Abu Za'arour, 2004), (Al Rapghy, 2005) that there is a relationship between motivation and the Mind habits, (Gial, 2006), (Charles B, 2011), (Al-Ja'afra, 2001), (Abu Hilal and Al-Tahan, 2002), (Nasef ,2010) which found that there is a relationship between creative thinking and academic achievement.

So, this confirmed the effectiveness of the study program based on the Mind habits in developing academic achievement motivation and creative thinking in Mathematics, as this program included non-traditional teaching methods such as; collaborative, individual, and interactive learning, learning by discovering, and the use of reinforcement. That will contribute significantly to the development of the 21 st-century learning skills (4C'S): Communication, Collaboration, Critical, and Creative Thinking in Mathematics. The main question was answered:

"What is the effectiveness of a program based on the Mind habits in developing academic achievement motivation and creative thinking in Mathematics among Prince Sattam Bin Abdulaziz University Students?"

\section{Research Recommendations}

1) Educational researchers should pay attention to the programs based on the Mind habits in the educational mathematical concepts' software construction.

2) Learning resources centers and mathematics laboratories in all public education stages should be developed and activated, and provide them with Mind habits programs.

3) Designing new preparing teachers' programs in the education faculties based on the Mind habits, concerning theories of learning and education.

4) Ministry of education should hold courses and seminars for teachers and supervisors of mathematics in designing and building programs based on the Mind habits.

\section{Research Proposals}

1) Conducting a similar study of this study:

A) In the Middle, high school, and other universities.

B) The curricula integrated into science and mathematics.

C) Finding out the impact of developing critical thinking skills and attitudes.

2) Studying the program impact based on the Mind habits during service on the attitude towards teaching.

\section{Acknowledgments}

Thanks: This project was supported by the Deanship of Scientific Research at Prince Sattam Bin Abdulaziz University under the research project: 2019/02/9718

\section{References}

Abdel Monem Alhefnee. (1994). Psychology Encyclopedia. Retrieved from www.philadelphia.edu.jo/.../205-psychology/23376-8999

Abdel Wahab, \& Fatima Mohamed. (2009). The Mind Habits and its relation to Teaching. Retrieved from http://Curriculum scianceblogSport.com

Abdel-Malik, Loris Emile. (2007). The Effectiveness of using teaching strategies on multiple intelligences to develop the achievement motivation related to science study in preparatory students, Unpublished PhD Thesis. Ismailia College Journal, Issue 8, April, pp. 117-186.

Abu Hilal, Maher Mohammed., Al., Tahan, \& Khalid, N. (2002). The relationship between innovative thinking, intelligence, and academic achievement in a sample of outstanding students in the UAE, Journal of Educational Research Center, Qatar University, Qatar, July2002, No22. 
Abu Za'arour, \& Rana Hamdallah. (2004). The Using Computer-Assisted Learning effect on Mathematics Achievement among Seventh Grade Students in Nablus City. Unpublished Master Thesis, Education Faculty, Al-Nagah National University, Nablus.

Al Atoom, Adnan Youssef., et al. (2009). Development of thinking skills, theoretical models, and practical applications. Dar Al-Massira for Publishing and distribution, No 2, Amman, Jordan.

Al Aza, saed. (2002). The talented and gifted education. Dar Elsaqafa for publishing\&distribution, Amman.

Al khouly, Hisham Mohamed. (2002). cognitive methods and disciplines in psychology. Alexandria, Modern Book House.

Al Qady, L., Hamdan, M., \& Saloum, T. (2016). The Mind habits level among preparatory pupils in the studies subject. Teshrein Journal for scientific researches, 1(2), Syria.

Al Rabghi, Khaled. (2005). Effect of a training program based on the Mind habits according to the Costa theory in thinking on the achievement motivation among students in the first secondary grade in Saudi Arabia, Unpublished master thesis, Balqaa University, Amman.

Aldapagh, Saer. (2008). A comparative study of the achievement and the self-copying among those who have high creative thinking from the secondary stage in Baghdad, M.D. Study in Educational Psychology, Literature faculty.

Al-Ghamdy, Abdullah Mohamed. (2000). Differences in self-concept and achievement motivation among adolescents deprived of the family and non-disadvantaged in Jeddah. unpublished master thesis, Education Faculty, Umm Al-Qura University.

Alharthy, Ibrahim Ahmed. (2007). the Mind habits and developing them among student. Riyadh: Al Shokri Library.

Al-Jaafra, Asmaa Abdul Hafez. (2001). A comparative study of innovative thinking and motivation of academic achievement and psychological compatibility among students who excel in different educational programs in Jordan, unpublished master thesis, Faculty of Education, Mustansiriya University, Iraq.

Almeshrefi, Enshrah. (2005). Learning the creative thinking, 1st edition, the Lebanese Egyptian Dar, Egypt.

Alqodah, Mohamed Farhan. (2014). The Mind Habits and its impediment of the achievement motivation among the Students of the Education College, King Saud University, The Arab Journal for the talent Development, 5(8), 33-59.

Al-Safy, Abdullah Taha. (2001). The School Climate and its Relation to the Achievement and the Ambition Level among students and secondary students in Abha City, Gulf Message journal, No. 79.

Al-Sawai, Othman Naif. (2004 AD). An effective mathematics teacher. Dar Al-Qalam Publishing and Distribution, Dubai, UAE.

Anncmie Desoete. (2007). Mind habits across the curlicue lump: Practical and supportive strategies, Supervision and curriculum Development Association (ASCD), Alexandria Virginia, USA. Retrieved from https://eric.ed.gov/?q=learning+with+our+5+senses\&ff1=autDesoete\%2c+Annemie

Aqeelan, Ibrahim Muhammad. (2000 CE). Mathematics Curricula and Teaching Methods, Jordan, Amman: Dar Al Masirah for Publishing, Distribution and Printing.

Badawi, Ramadan Massad. (2008 AD). Including Mathematical Thinking in School Mathematics Programs, Jordan, Amman: Dar Al-Fikr for Publishing and Distribution.

Chan Min Kim, \& Charles B. Hodges. (2011). Effect of an Emotion Control Treatment Emotions, motivation and achievement in an online mathematics course, Instructional Science, Online First ${ }^{\mathrm{TM}}, 4$ March. Retrieved from http://www.springerlink.com/content/?k=achievement+motivition+in+mathematic\&o=10

Chulvi, V., Mulet, E., Chacrabarti, A., Lopez-Mesa, B., \& Gonzalez-Cruz, C. (2012). Comparison of the degree of creativity in the design outcomes using different design Methods, Journal of Engineering Design, 23(4), $241-269$. https://doi.org/10.1080/09544828.2011.624501

Costa, A, L., \& Kallick, B. (2000). Discovering \& Exploring Mind habits. Supervision \& Curriculum Development Association. Alexandria, VA: ASCD. Retrieved from https://eric.ed.gov/?id=ED439101

Ellen, J. (2001). Using the science teaching standards to nature the Mind habits in the middle school students, (Master of education), education school, pacific Lutheran university. 
El-Sayed, Omnia., \& Ahmed, Naima. (2005). The Effect of Using the Sushman Model for survey training in the Scientific Survey development and Integrative Science Processes and the achievement motivation among postgraduate Students, Scientific Education Journal, Egyptian Scientific Education organization, Volume 8, No. 1, March.

Elsayed, Sahar Abdo. (2012). A program Based on the computer interactive engineering simulation and its impact on achievement motivation in primary school students, Education Faculty Journal in Port Said, Faculty of Education, Port said University, Egypt, vol. 12, January, pp. 410-430.

Elsayed, Sahar Abdo. (2016). The Effectiveness of Using Interactive Computer Program in Developing the Mathematical Power Skills among Prince Sattam University Students, Mathematics Education Journal, Faculty of Education, Banha University, Egypt, Vol. 19, No. 6, April-2016, Part3, 195- 227.

Elsayed, Sahar Abdo. (2019). Project-Based Mathematics Learning in the Age of Innovation and Entrepreneurship among Prince Sattam University Students, The Arab Journal for Training and Development Research, Banha University, Egypt. Vol. 2, No. 6, April-2019, 176-195.

Gail, V. (2006). Teacher Research as A Mind Habit, Education Master, Gorge Mason University. Retrieved from www.aun.edu.eg/faculty_childhood/5m.pdf

Garwan, Fathy. (1999). Learning thinking Concepts and applications, University book Dar, Al Ain, United Emirates.

Ghandoura, Abbas Hassan. (1997 AD). Teaching Mathematics by Handicrafts, Jeddah: Mirza Library.

Kairalla, Sayed. (1975). The creative thinking test (educational and psychological researches), Dar Elnahda, Egypt.

Khairalla, Sayed. (1981). Educational Psychology, Dar Elnahda, Egypt.

Lotfallah, Nadia Samaan. (2005). The impact of Think- participate Strategy use - in the achievement and creative thinking and the achievement motivation among the fourth grade Students with disabilities, Scientific Education Journal, Volume VIII, September.

Mansour, Roshdy Pham. (1997). The Influence impact of the Statistical Significance Phenomenon, Egyptian Journal of Psychological Studies, 7(16).

Manssi, Mahmoud. (1991). kindergarten and children creativity, Dar Elmaarefa, Alex.

Marzano, R., Pickering, D., \& Mc Tighe J. (1993). Assessing student outcomes: performance assessment using the learning model dimensions, Alexandria Va.: Supervision and Curriculum Development Association. Retrieved from https://eric.ed.gov/?id=ED461665

Moawad, Khalil. (2000). Mind abilities, 1st edition, Dar Elmaaref, Alex.

Moussa, Farouk Abdel-Fattah. (1991). The achievement motivation test for children and adults, Cairo, Al Nahda library, second print.

Nasef, Heba Mohamed. (2010). The Effectiveness of Enrichment Programs in developing the achievement motivation level among underachieving gifted pupils, Girls College of Literature, Science and Education, Ain Shams University.

Qatami, Yousef. (2007). Thirty Mind Habits, Dar De Bono Publishing, Amman, Jordan.

Qatami, Yousef., \& Sobhy, Tayseer. (1992). Introduction to talent and creativity, Dar Al Faris for Publishing and Distribution, Amman, Jordan.

Rosnow, R. L., \& Rosenthal, R. (1996). Computing contrasts, effect sizes, and counter nulls on other people's published data: General procedures for research consumers. Psychological Methods, 1(4), 331-340. https://doi.org/10.1037/1082-989X.1.4.331

Said, Ayman Habib. (2006). The Impact of (Ask-Exploratory) Strategy use on the Development of the Mind Habits among First Grade Students through Chemistry, the 10th Scientific Conference, "The Age and Future Perspectives challenges", (2), July 3 to August, 30/7-1/8/2006, Ismailia, pp. 464-260.

Saleh, Magda Mahmoud. (2006 AD). Contemporary Trends in Mathematics Education, Jordan, Amman: Dar Al-Fikr for Publishing and Distribution.

Sawyer et al. (1990). Towards a theory of Organizational Creativity, The Academy of management review, 18(2). Retrieved

from https://www.researchgate.net/publication/234022043_Toward_a_Theory_of_Organizational_Creativity 
Stephen covey. (2000). leaning Mind habits, highly effective people seven habits, supervisor and curriculum development assosciation, USA. Retrieved from https://en.wikipedia.org/wiki/The_7_Habits_of_Highly_Effective_People

Sttouhi, Manal Farouk. (2011). Optional models use in the media for ongoing events with graphic organizations in teaching statistics to develop statistical sense and some Mind habits and achievement motivation among students in the preparatory stage, the Egyptian Curriculum and Teaching Methods organization, Education college, Ain Shams University.

Varol, F., \& Farran, D. (2007). Elementary school students Mind computation proficiencies. Early Childhood Education Journal, 35(1), 89-94. https://doi.org/10.1007/s10643-007-0173-8

\section{Notes}

Note 1. Appendix (1): Academic achievement motivation in mathematics scale.

Note 2. Appendix (2): Creative thinking skills in mathematics test. 


\section{Appendix 1}

\section{Academic achievement motivation in mathematics scale}

\section{Scale instructions:}

(1) The scale aims to measure the academic achievement motivation in mathematics.

(2) The scale consists of 25 items.

(3) Each student has to choose one of the three options.

(4) Mark $(\sqrt{ })$ in the opposite box of each item, to indicate the extent to which these statements apply to your achievement behavior.

(5) There is no correct or wrong answer, as the chosen answer expresses personal opinion.

(6) The time limit for the scale is 20 minutes.

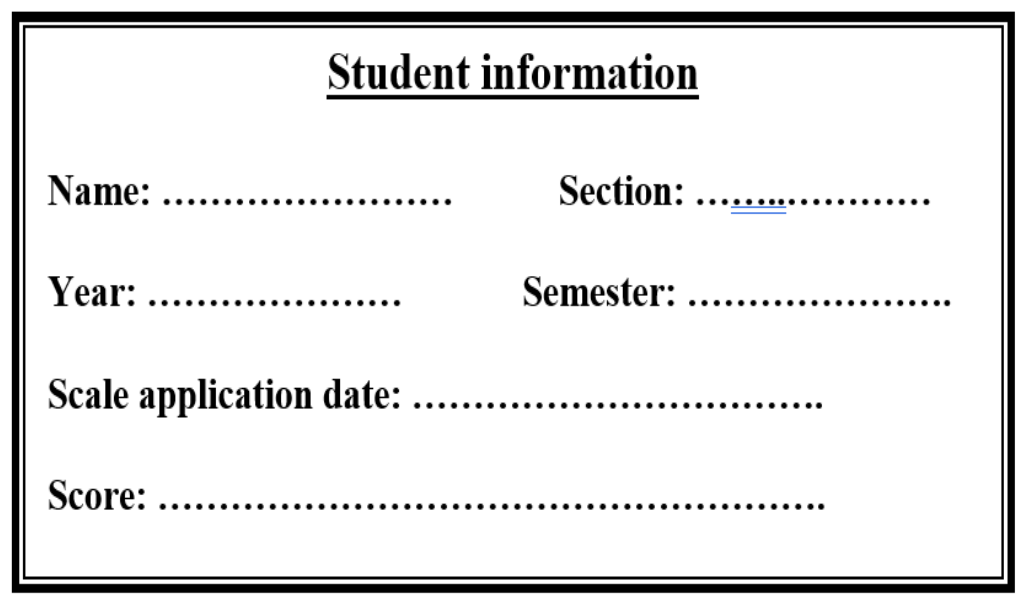




\section{Academic achievement motivation in mathematics scale}

\begin{tabular}{|c|c|c|c|c|}
\hline \multirow[t]{2}{*}{ No. } & \multirow[t]{2}{*}{ Item } & \multicolumn{3}{|c|}{ Answer } \\
\hline & & identical & $\begin{array}{l}\text { Not } \\
\text { Sure }\end{array}$ & nonidentical \\
\hline 1 & I continue the work I started until I finish it. & & & \\
\hline 2 & $\begin{array}{l}\text { My failure in doing math homework is due to a lack } \\
\text { of effort. }\end{array}$ & & & \\
\hline 3 & $\begin{array}{l}\text { I solve questions to learn how to answer, not because } \\
\text { I was assigned to do so. }\end{array}$ & & & \\
\hline 4 & $\begin{array}{l}\text { I feel bored when discovering new things in } \\
\text { mathematics. }\end{array}$ & & & \\
\hline 5 & $\begin{array}{l}\text { The work required by the mathematics teacher has } \\
\text { been completed to the fullest. }\end{array}$ & & & \\
\hline 6 & $\begin{array}{l}\text { I avoid engaging in geometric activities that rely on } \\
\text { observation with my colleagues. }\end{array}$ & & & \\
\hline 7 & $\begin{array}{l}\text { I leave immediately any topic that I find difficult to } \\
\text { understand while studying mathematics. }\end{array}$ & & & \\
\hline 8 & $\begin{array}{l}\text { I prefer geometric situations with a bit of adventure } \\
\text { and risk-taking than ordinary things. }\end{array}$ & & & \\
\hline 9 & $\begin{array}{l}\text { I Postpone the completion of anything I started in } \\
\text { math. }\end{array}$ & & & \\
\hline 10 & I much benefit from training in mathematics. & & & \\
\hline 11 & $\begin{array}{l}\text { Difficult mathematical problems appeal to me more } \\
\text { than medium difficulty problems. }\end{array}$ & & & \\
\hline 12 & I have the determination to win math competitions. & & & \\
\hline 13 & $\begin{array}{l}\text { I keep doing the thing even if it takes a long time to } \\
\text { complete. }\end{array}$ & & & \\
\hline 14 & $\begin{array}{l}\text { I prefer watching TV and listening to radio than } \\
\text { reading a new book on mathematics. }\end{array}$ & & & \\
\hline 15 & I do all my best in any work for fear of failure. & & & \\
\hline 16 & $\begin{array}{l}\text { I avoid asking my friends what they think before I } \\
\text { decide what to do. }\end{array}$ & & & \\
\hline 17 & $\begin{array}{l}\text { I need short periods of rest whenever I successfully } \\
\text { complete part of my business. }\end{array}$ & & & \\
\hline 18 & $\begin{array}{l}\text { My enthusiasm and activity decrease when I feel I } \\
\text { am facing a difficult task. }\end{array}$ & & & \\
\hline 19 & $\begin{array}{l}\text { I rarely enjoy being an innovator or maker of new } \\
\text { things. }\end{array}$ & & & \\
\hline 20 & I often find myself talking about the future. & & & \\
\hline 21 & $\begin{array}{l}\text { I enjoy presenting important activities, examples and } \\
\text { exercises to my colleagues. }\end{array}$ & & & \\
\hline 22 & $\begin{array}{l}\text { I feel tired and bored shortly after the start of my } \\
\text { assigned work. }\end{array}$ & & & \\
\hline 23 & I feel annoying when studying math topics. & & & \\
\hline 24 & $\begin{array}{l}\text { My primary goal is to succeed in performing any } \\
\text { mathematics task. }\end{array}$ & & & \\
\hline 25 & I ask many questions, wanting to learn all new. & & & \\
\hline
\end{tabular}




\section{Appendix 2}

\section{Creative thinking skills in mathematics test}

\section{instructions:}

Dear Student, before you start answering this test, you should read these instructions carefully because they will help you answer correctly:

(1) The scale aims to measure your ability to think creatively in mathematics, it consists of 12 questions, each question has a very large number of different correct solutions.

(2) The degree you obtain is not related to success in mathematics.

(3) The scores for this test do not have a specific maximum term mark.

(4) Try to answer all questions in the designated places of the question paper, and you can use an external sheet if necessary, and do not leave any question without thinking about it in the greatest number of ways.

(5) Make sure that the answers you write for each question is different and you do not need to repeat any of them.

(6) Do not start answering until asked.

(7) Do not write your name on the answer sheet, but write the number your professor will tell you.

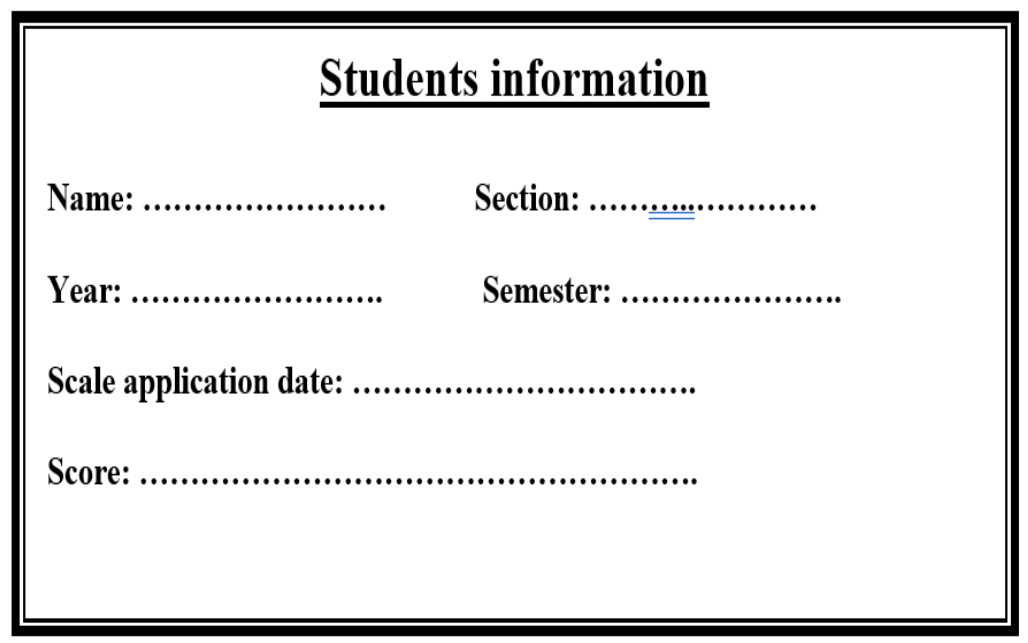


1- Mention as many expressions as possible that express the concept of the square.

a.

c.

e.

g.

i. b.

d.

f.

h.
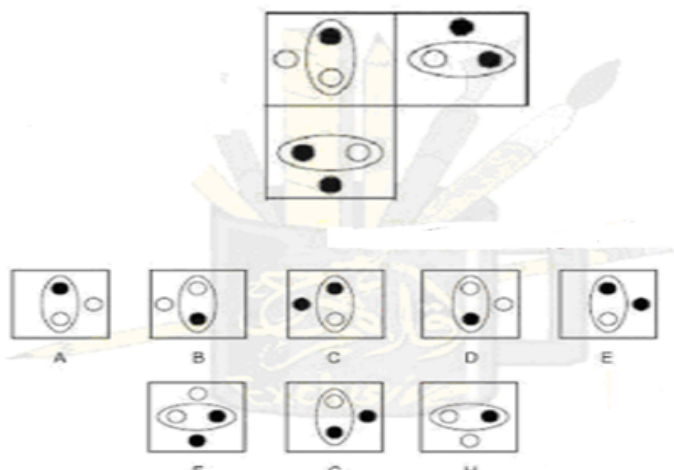

Which square is missing?

3- The following three figures are divided into identical congruent triangles.

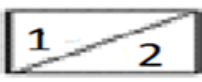

Figure (1)

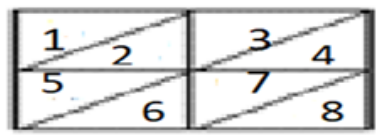

Figure (2)

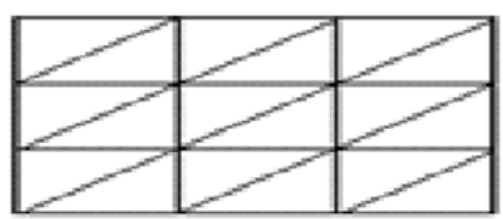

Figure (3)

A. Complete the following table: first write the small triangles number that make up Figure 3.

Next, determine the small triangles number of that Figure 4 will need to form if the sequence of continues shapes to appear.

\begin{tabular}{|c|c||}
\hline FIGURE & SMALL TRIANGLES NUMBER \\
\hline $\mathbf{1}$ & $\mathbf{2}$ \\
\hline $\mathbf{2}$ & $\mathbf{8}$ \\
\hline $\mathbf{3}$ & \\
\hline $\mathbf{4}$ & \\
\hline
\end{tabular}

B. When shapes continue to appear until Figure 7. What The small triangles number you will need to form Figure 7?

C. When shapes continue to appear until Figure 50. Explain how to find The small triangles number you will need to form Figure 50, So that this method does not depend on drawing the figure and counting the triangles?

Answer: 
4-In front of you, there are three straight segments. What are the additions that can be added to form different symmetrical geometric shapes?

You can draw just one straight line to help you in drawing some shapes.

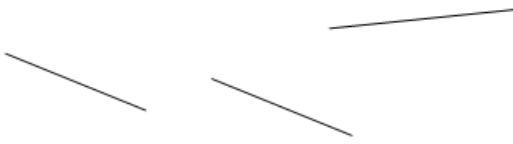

a.

c.

e.

g.

i.

5 - Write as many geometric patterns as possible using these shapes, and then discover the numerical pattern with which you are going.
(2)
(2)
()
(2)
()
()
()
(2)
() ()
(2) (2)

b.

d.

f.

h.
(2)
1-

3-

$5-$

7-

9-

The numerical pattern is:
2-

4-

6-

8-

$10-$

6- Write down all the life and scientific problems you can think of that occur as a result of the knowledge lack of geometrical science.

\begin{tabular}{|l|l|}
\hline No. & \multicolumn{1}{c|}{ Problem } \\
\hline & \\
\hline & \\
\hline & \\
\hline & \\
\hline & \\
\hline & \\
\hline
\end{tabular}


7- In the following figure:

$A B C D$ is a rhombus in which its side length is $x$, several other rhombus are drawn sequentially as shown below, so that any side of the rhombus is equal to half the length of the side directly before it. Write the largest possible number of different and various math relationships that you can reach with the results of this exercise.

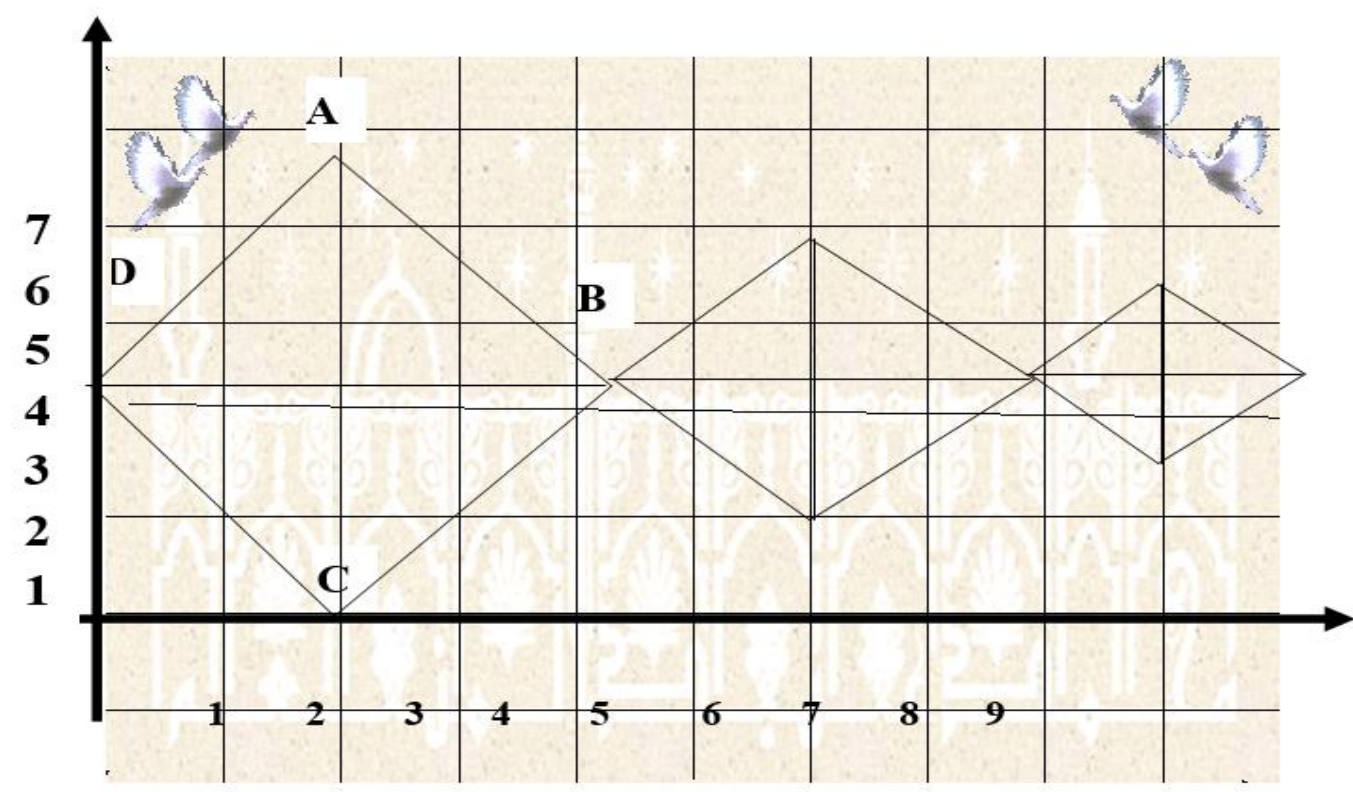

$1-$

3-

$5-$

2-

4-

6-

8- Write down the life and scientific problems you can think of that may arise from the mathematicians' failure to discover patterns.

\begin{tabular}{|l|l|}
\hline No. & \\
\hline & \\
\hline & \\
\hline & \\
\hline & \\
\hline & \\
\hline & \\
\hline & \\
\hline
\end{tabular}

9- Separate or expand the following shape by removing or adding straight segments to make this shape symmetrical.

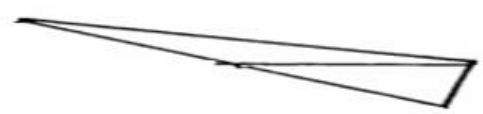


10- The following pattern is Pascal's triangle. Discover the pattern, and form a geometric pattern of this visual one.

$$
\begin{gathered}
1 \\
232 \\
3443 \\
45554 \\
000000 \\
00000000 \\
000000000 \\
0000000000 \\
000000000000 \\
0000000000000 \\
0000000000000
\end{gathered}
$$

The pattern:

11- In the following figure:

Write as many mathematical relationships as you can access using the data from this exercise.

(A) The coordinates of points A, B, C, D.

(B) The pattern

(C) The Congruence.

(D) The Symmetry.

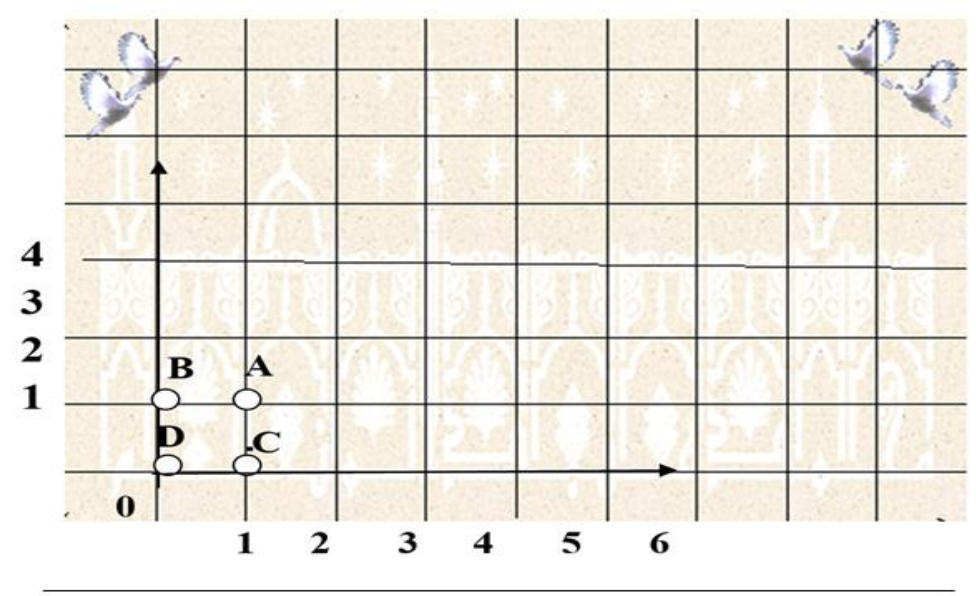

12- What are the additions that can be made to this circular sequence to give different object expressions?

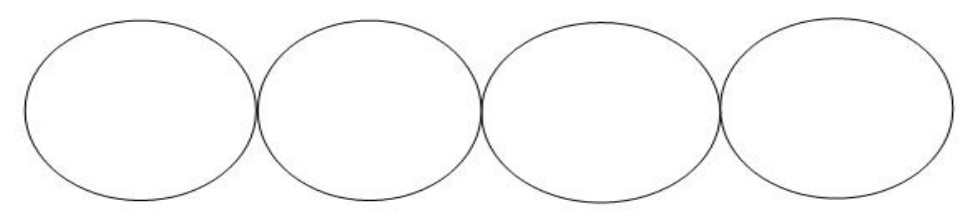

5

\section{Copyrights}

Copyright for this article is retained by the author(s), with first publication rights granted to the journal.

This is an open-access article distributed under the terms and conditions of the Creative Commons Attribution license (http://creativecommons.org/licenses/by/4.0/). 